\title{
Inhibition of lipopolysaccharide synthesis in Agrobacterium tumefaciens and Aeromonas salmonicida
}

\author{
Robert C. Goldman, ${ }^{1 *}$ John O. Capobianco, ${ }^{1}$ Colette C. Doran ${ }^{1}$ and Ann G. Matthysse ${ }^{2}$ \\ ${ }^{1}$ Anti-Infective Research Division, Abbott Laboratories, Abbott Park, Illinois 60064-3500, USA \\ ${ }^{2}$ Department of Biology, University of North Carolina, Chapel Hill, North Carolina 27599, USA
}

(Received 8 November 1991; revised 14 February 1992; accepted 11 March 1992)

\begin{abstract}
Lipopolysaccharide (LPS) synthesis was inhibited, new lipid A metabolites accumulated, and growth ceased, when the plant pathogen Agrobacterium tumefaciens and the fish pathogen Aeromonas salmonicida were treated with an antibacterial agent which specifically inhibits CTP:CMP-3-deoxy-manno-octulosonate cytidylyltransferase (CMP-KDO synthase). The new lipid A metabolites were purified by chromatography on DEAE-cellulose and chemically analysed. Metabolites isolated from both bacterial species contained glucosamine and phosphate in a 1:1 molar ratio, and 3-OH-C14:0 was the major fatty acid present (1 mol and 1.4 mol per mol glucosamine for $A$. tumefaciens and $A$. salmonicida, respectively). Inhibition of LPS synthesis by CMP-KDO synthase inhibitor had no effect on the initial kinetics of $A$. tumefaciens attachment to cultured carrot cells, but did inhibit cell aggregation normally induced by bacterial cellulose synthesis. Bacteria treated with inhibitor remained viable and able to synthesize protein at $15 \%$ the rate of control cells, indicating that the lack of cellulose-induced aggregation was not due to the inability of bacteria to make protein, but rather the inability to respond normally to the bacterialplant cell interaction.
\end{abstract}

\section{Introduction}

Lipopolysaccharide (LPS) is a major component of Gram-negative bacteria that serves important roles in outer membrane structure and function, including the interaction of pathogens with their hosts. LPS from most Gram-negative organisms contains 3-deoxy-D-mannooctulosonate (KDO) which serves as a link between lipid $\mathrm{A}$ and core oligosaccharide units. The pathway of KDO synthesis and incorporation into LPS is known (Ray et al., 1982) and specific inhibitors of one of the enzymic steps [CTP : CMP-3-deoxy-D-manno-octulosonate cytidylyltransferase (CMP-KDO synthase)] have been designed (Capobianco et al., 1987) and transformed into antibacterial agents (Goldman et al., 1987). These new antibacterial agents have proven useful in the investigation of the early steps in synthesis and assembly of LPS in various Gram-negative bacteria (Goldman et al., 1988a, b, 1990; Kadam et al., 1989).

\footnotetext{
* Author for correspondence. Tel. (708) 9374477 ; fax (708) 9386603.

Abbreviation: KDO, 3-deoxy-D-manno-octulosonate.
}

LPS synthesis ceases following addition of this new class of antibacterial agents to growing bacteria, resulting in accumulation of precursors to LPS as well as other lipid-A-related metabolites (Goldman et al., 1987, $1988 a, b ;$ Kadam et al., 1989). Both the direct precursor to LPS and the lipid-A-related side-products are capable of translocation to the outer membrane (Goldman et al., 1990; Osborn et al., 1980) resulting in an outermembrane surface with reduced density of LPS (Goldman et al., 1989). The level of porin protein in the outer membrane is also reduced by more than $50 \%$ (Goldman et al., 1990). These alterations of outer-membrane structure result in increased sensitivity to other antibacterial agents and host immunodefenses (Goldman et al., 1987). The investigations summarized above were limited to several species of enteric (Salmonella, Escherichia, Serratia, Providencia, Citrobacter, Enterobacter) and one species of non-enteric (Pseudomonas aeruginosa) Gram-negative bacteria. More recently we have turned our attention to other non-enteric pathogens of fish and plants (Goldman et al., 1990).

Agrobacterium tumefaciens is a non-enteric Gramnegative pathogen which causes crown gall tumour 
disease in wounded dicotyledonous plants (Lippincott \& Lippincott, 1975). The sequence of basic events leading to an established infection is summarized as follows: (i) attachment of bacteria to plant cells exposed at wound sites; (ii) bacterial synthesis of cellulose fibrils and formation of bacterial aggregates; (iii) transfer of plasmid DNA; (iv) integration of Ti DNA into the plant genome; (v) alteration of plant growth hormone production; and (vi) establishment of crown gall tumour disease wherein the bacteria derive nutrients from the altered plant system. Aeromonas salmonicida is a pathogen of salmonid fish, capable of causing severe disseminated disease (Klontz et al., 1966). In this report we have used specific inhibitors of CMP-KDO synthase to investigate the assembly of LPS in A. salmonicida and $A$. tumefaciens, and the effects of LPS inhibition in A. tumefaciens on the initial events in the interaction with plant cells.

\section{Methods}

Bacterial strains and growth conditions. A. tumefaciens strains A61 and A136 (biotype 1), 3R32 (biotype 2) and Ag63 (biotype 3) were obtained from M. Thomashow (Michigan State University, East Lansing), while strain A6 (also biotype 1) was from the laboratory collection (A. Matthysse). A. salmonicida subsp. salmonicida strain ATCC 33658 was obtained from the American Type Culture Collection, Rockville, MD. Salmonella typhimurium LT2 strain RG111 was from the laboratory collection (R. Goldman). Bacteria were grown in MOPS defined medium (Neidhardt et al., 1974) at $30^{\circ} \mathrm{C}$ using glucose as the carbon source. $N$-Acetyl-D-glucosamine was added to $0.5 \mathrm{mM}$ concentration when bacteria were radiolabelled with $N$-acetyl-D- $\left[1-{ }^{3} \mathrm{H}\right]$ glucosamine (Amersham). Sodium acetate $(1 \mathrm{mM})$ was added when cells were radiolabelled with $\left[{ }^{3} \mathrm{H}\right]$ acetate $\left(20 \mu \mathrm{Ci} \mathrm{ml}^{-1}\right.$, Amersham). Casamino acids (Difco) was added to $1 \mathrm{mg} \mathrm{ml} \mathbf{l}^{-1}$ to support growth of $A$. salmonicida. Sensitivity to antibacterial agents was determined by microtitre broth dilution and measurement of zones of growth inhibition by disk diffusion ( $1 \mu \mathrm{mol}$ test compound per disk) in soft agar overlays (Goldman et al., 1987).

Analysis of inhibitor effects on LPS synthesis. Methods for analysis of inhibitor effects on LPS synthesis were previously described (Goldman et al., 1987, 1988a, b; Kadam et al., 1989). The inhibitor used was compound IV in our previous nomenclature (Goldman et al., 1987) which is $\alpha$-C-[1,5-anhydro-7-amino-2,7-dideoxy-D-manno-heptopyranosyl]carboxylate in amide linkage to the carboxyl terminus of Lalanylalanine (US Patents 4613589 and 4613590). Briefly, antibacterial agent was added to exponentially growing cultures of bacteria in MOPS medium containing $0.5 \mathrm{~mm}-N$-acetyl-D-glucosamine, followed immediately by addition of $N$-acetyl-D- $\left[1-{ }^{3} \mathrm{H}\right]$ glucosamine to $4 \mu \mathrm{Ci}$ $\mathrm{ml}^{-1}$, or $\left[{ }^{3} \mathrm{H}\right]$ acetate to $20 \mu \mathrm{Ci} \mathrm{ml}^{-1}$. At the indicated times, samples were harvested, washed twice with $0.01 \mathrm{M}$-HEPES/NaOH buffer, $\mathrm{pH} 7 \cdot 2$, and when indicated, delipidated by extraction with $95 \%$ ethanol, followed by acetone and then diethyl ether. Glycolipids were extracted with acidic methanol, partitioned into chloroform, and analysed by chromatography on Silica Gel H TLC plates developed in chloroform/pyridine $/ 88 \%$ formic acid/40:60:16:5 $\mathrm{H}_{2} \mathrm{O}$, (Goldman $e t$ al., 1988a; Raetz et al., 1985). Radioactive spots were eluted from the silica gel with chloroform $/$ methanol/ $\mathrm{H}_{2} \mathrm{O}(63: 33: 4$, by $\mathrm{vol} / \times 2)$ containing $0 \cdot 1 \mathrm{M}-\mathrm{HCl}$. Fatty acid methyl esters were generated by refluxing in methanolic $\mathrm{HCl}$ (Alltech Associates) at $100^{\circ} \mathrm{C}$ for $17 \mathrm{~h}$ (Capobianco et al., 1987). Fatty acids were extracted into chloroform as follows. An equal volume of chloroform was added followed by $0.1 \mathrm{vol}$. $99 \%(\mathrm{v} / \mathrm{v})$ formic acid and $0.4 \mathrm{vol}$. water added slowly with mixing. After phase separation, the chloroform phase was removed. The aqueous phase was re-extracted with another $1.0 \mathrm{ml}$ chloroform, and the chloroform fractions were pooled and washed with 0.5 vol. water. The chloroform extracts were analysed by argentation chromatography on $20 \% \mathrm{AgNO}_{3}$-impregnated silica gel plates developed in chloroform/ethanol $(99: 1)$.

Purification and chemical analysis of lipid A metabolites. Lipid A metabolites radiolabelled with $N$-acetyl-D- $\left[1-{ }^{3} \mathrm{H}\right]$ glucosamine were extracted, purified and analysed as described previously (Goldman $e t$ $a l ., 1988 a, b)$. Briefly, washed cells were delipidated by extraction with $95 \%(\mathrm{v} / \mathrm{v})$ ethanol, followed by acetone and then diethyl ether, and extracted several times with phenol/chloroform/petroleum ether $(2: 5: 8)$. The extract was evaporated to the phenol phase, which was loaded on to a DEAE-cellulose column equilibrated with methanol containing $1 \%(\mathrm{v} / \mathrm{v})$ acetic acid. The column was washed with equilibration buffer and eluted with a linear gradient of 0 to $1 \mathrm{M}$ ammonium acetate. Radioactive peaks of interest were pooled, and material was extracted into chloroform as described previously (Goldman et al., 1988a,b). A modification of the Elson-Morgan reaction (Levvy \& McAllen, 1959; Reissig et al., 1955) was used to determine glucosamine content after hydrolysis in $4 \mathrm{M}-\mathrm{HCl}$ at $100^{\circ} \mathrm{C}$. Phosphate content was determined by the method of Ames (1966). The fatty acid content of fractions were determined by gas chromatography. Samples containing the internal standard heptadecanoic acid were converted to methyl esters with $1.0 \mathrm{ml}$ methanolic $\mathrm{HCl}$, and extracted into chloroform (see above). The samples in chloroform were taken to dryness, and resuspended in a small volume of chloroform prior to injection into a $6 \mathrm{ft}$ ( $2 \mathrm{~mm}$ diameter) glass column packed with $3 \%$ (w/v) SE30 on Gas-Chrom Q (80/100 mesh, Supelco). Analysis was done isothermally at $190^{\circ} \mathrm{C}$ on a Hewlett-Packard model 402 gas chromatograph equipped with a flame ionization detector and a Varian model 4270 integrator. Values were determined in triplicate and standard deviations are reported.

Measurement of protein synthesis. Bacteria were grown in MOPS medium at $30^{\circ} \mathrm{C}$ containing $180 \mu \mathrm{M}-\mathrm{L}$-phenylalanine and labelled by addition of $\left[{ }^{14} \mathrm{C}\right] \mathrm{L}$-phenylalanine (Amersham, $513 \mathrm{mCi} \mathrm{mmol}^{-1}$ ) to $1.7 \mu \mathrm{Ci} \mathrm{ml}^{-1}$. Radiolabelled phenylalanine was evaporated to dryness prior to use in order to remove ethanol. Duplicate culture samples $(0.5 \mathrm{ml})$ were removed and further incorporation of label stopped by mixing with $0.5 \mathrm{ml}$ cold $10 \%$ (w/v) TCA containing $100 \mu \mathrm{g} \mathrm{ml}^{-1}$ unlabelled phenylalanine. Samples were collected on $\mathrm{GF} / \mathrm{F}$ glass fibre filters (Whatman) and washed 3 times with $5 \mathrm{ml} 5 \%(\mathrm{w} / \mathrm{v})$ TCA containing $50 \mu \mathrm{g}$ unlabelled phenylalanine $\mathrm{ml}^{-1}$ followed by $5 \mathrm{ml}$ cold $95 \%(v / v)$ ethanol. Radioactivity was measured by liquid scintillation counting.

Bacterial interaction with carrot cells. The interaction of bacteria with cultured carrot cells was previously described by Matthysse $e t$ al. (1978). Briefly, bacteria grown in MOPS were either tested directly (control) or following exposure to the LPS inhibitor for 3-4 h, or overnight. The fraction of added bacteria attached to carrot cells was measured by viable count of free and bound bacteria. The formation of cellulose-dependent aggregates was assessed at $24 \mathrm{~h}$ (Matthysse $e t$ al., 1981).

Chemicals. Radiochemicals were obtained from Amersham. Methanolic $\mathrm{HCl}$ kits were from Alltech Associates. DEAE-cellulose was from Whatman. 3-OH-Cl4:0 for use as a standard was synthesized chemically (Pugh et al., 1966). Fatty acids (C14:0, C16:0, C17:0 and $\mathrm{C} 18: 1)$ and all other chemicals were from Sigma. 


\section{Results and Discussion}

Sensitivity of A. tumefaciens and A. salmonicida strains to CMP-KDO synthase inhibitor.

A. tumefaciens biotype 1 strains grew well in MOPS defined medium with glucose as the carbon source $\left(\mu=0.57\right.$ at $\left.30^{\circ} \mathrm{C}\right)$. The MIC for compound IV, determined by broth dilution, was $10 \mu \mathrm{g} \mathrm{ml}^{-1}$ and zones of growth inhibition (Goldman et al., 1987) were clearly observed by disk diffusion (18-35 mm). Strain A61 was also sensitive to tri-L-ornithine (14 mm zone of inhibition) while strain A136 appeared resistant (no zone detectable). The MIC for compound IV was $10 \mu \mathrm{g} \mathrm{ml}^{-1}$ on $S$. typhimurium RG111, and this strain was also sensitive to tri-L-ornithine ( $22 \mathrm{~mm}$ zone of inhibition). $A$. tumefaciens biotype 2 and 3 strains grew poorly in MOPS glucose medium. Although they were sensitive to compound IV, they were not studied further. The $A$. tumefaciens biotype 1 strains were as sensitive to compound IV as most enteric Gram-negative bacteria previously tested (Goldman et al., 1987, 1988 b; Kadam et al., 1989; unpublished data); however, they appeared less sensitive to tri-L-ornithine. Both tri-L-ornithine (Bark \& Gilvarg 1974) and compound IV (Goldman et al., 1987) enter Gram-negative bacteria by way of the oligopeptide transport (Opp) system. Inhibitory action of compound IV requires cleavage by intracellular peptidase (Goldman et al., 1987), whereas tri-L-ornithine inhibits protein synthesis directly (Bark \& Gilvarg 1974). A. tumefaciens strains appear to contain a functional Opp system and appropriate intracellular peptidase activity to release the CMP-KDO synthase inhibitor from the peptide carrier. Genetic defects inactivating the Opp system occur at high frequency in most Gram-negative enteric bacteria (Hiles et al., 1987, and unpublished data). In contrast, mutants resistant to compound IV were present at a frequency of less than $10^{-8}$ in cultures of $A$. tumefaciens biotype 1 strains, and growth remained inhibited during overnight incubation with compound IV (Fig. 1). A. salmonicida was sensitive to compound IV ( $23 \mathrm{~mm}$ inhibition zone) with an MIC in broth dilution of $50 \mu \mathrm{g} \mathrm{ml}^{-1}$.

\section{Mode of action of compound IV on A. tumefaciens biotype 1 strains and $A$ salmonicida}

The antibacterial activity of compound IV is limited to Gram-negative bacteria, and inhibition of LPS synthesis at the level of CMP-KDO synthetase was its mode of action for several species of Gram-negative enteric bacteria (Capobianco et al., 1987; Goldman et al., 1987, $1988 a, b$; Kadam et al., 1989). Inhibition of LPS synthesis caused accumulation of both direct precursor to

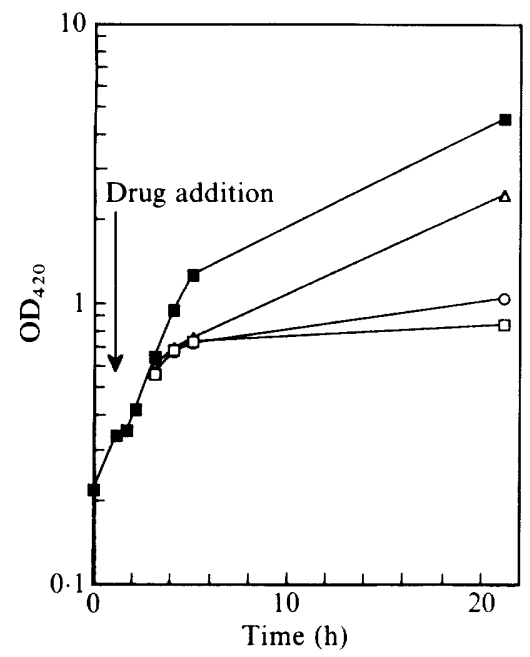

Fig. 1. Effect of inhibitor on growth of A. tumefaciens strain 136. Bacteria were grown in MOPS medium at $30^{\circ} \mathrm{C}$ and varying amounts of inhibitor were added (downward arrow; $\mathbf{0}, 0 \mu \mathrm{g} \mathrm{ml}^{-1} ; \triangle$, $10 \mu \mathrm{g} \mathrm{ml}^{-1}$; $\mathrm{O}, 20 \mu \mathrm{g} \mathrm{ml}^{-1} ; \square, 40 \mu \mathrm{g} \mathrm{ml}^{-1}$ ). Growth was monitored as $\mathrm{OD}_{420}$.

LPS as well as lipid-A-related byproducts, and halted growth. The following results show that the same mode of action is responsible for antibacterial activity on $A$. tumefaciens biotype 1 strains and $A$. salmonicida. Essentially identical results were obtained with the three $A$. tumefaciens biotype 1 strains examined; only data derived from strain A136 will be presented.

Growth of $A$. tumefaciens gradually ceased following addition of compound IV in excess of $10 \mu \mathrm{g} \mathrm{ml}^{-1}$ (Fig. 1). Only labelled phospholipid was extracted by delipidation of control or drug-treated cells (data not shown). LPS and residual phospholipid were extracted, by acidic methanol, from control cells radiolabelled with $N$-acetyl-D$\left[1-{ }^{3} \mathrm{H}\right]$ glucosamine (Fig. $2 a$ ). In contrast, when cells were treated with compound IV, incorporation of label into LPS decreased and two new metabolites appeared that were labelled with $N$-acetyl-D- $\left[1-{ }^{3} \mathrm{H}\right]$ glucosamine (Fig. $2 a$ ). Quantitative analysis revealed that LPS synthesis was inhibited by more than $90 \%$, and that the two new metabolites were undetectable in control cells $(<5 \%$ of the amount present in treated cells). These new metabolites were also radiolabelled with acetate, recovered from the TLC, and the labelled lipid was converted to fatty acid methyl esters for analysis by argentation chromatography. This technique separates the saturated, unsaturated and hydroxy classes of fatty acid methyl esters. Hydroxy fatty acids represented $>93 \%$ of the fatty acids released from the major and minor new metabolites that accumulated in biotype 1 strains. In contrast, the fatty acid methyl esters released from phospholipid contained 


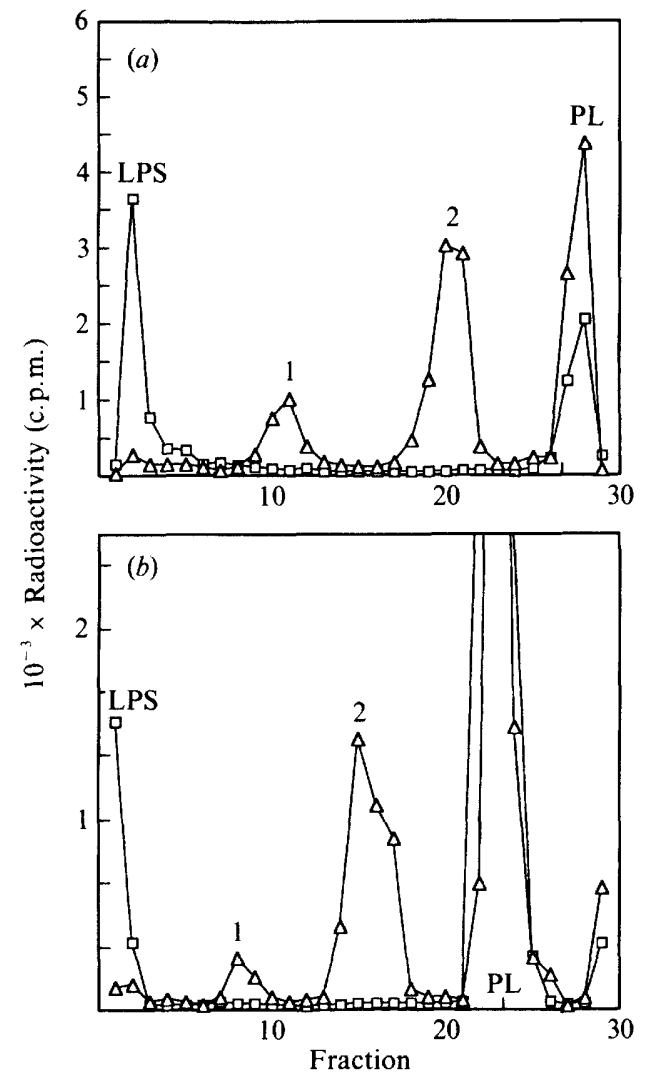

Fig. 2. Analysis of inhibitor effect on LPS synthesis. Bacteria were grown in MOPS medium to an $\mathrm{OD}_{420}$ of $0 \cdot 2-0 \cdot 4$. Inhibitor was then added $\left(20 \mu \mathrm{g} \mathrm{ml}^{-1}\right.$ for $A$. tumefaciens, $50 \mu \mathrm{g} \mathrm{ml}^{-1}$ for $A$. salmonicida) followed immediately by $N$-acetyl-D- $\left[1-{ }^{3} \mathrm{H}\right]$ glucosamine to $4 \mu \mathrm{Ci} \mathrm{m} l^{-1}$ $\left(148 \mathrm{kBq} \mathrm{ml}^{-1}\right)$, and bacteria were harvested by centrifugation $5 \mathrm{~h}$ later (a) A. tumefaciens strain 136 control $(\square)$ and inhibitor-treated $(\triangle)$ cells were delipidated, and glycolipids extracted and analysed by TLC on Silica Gel H plates. (b) Glycolipids were extracted directly from $\boldsymbol{A}$. salmonicida control $(\square)$ and inhibitor-treated $(\triangle)$ cells without prior delipidation, and analysed by TLC on Silica Gel H plates. LPS, lipopolysaccharide; PL, phospholipid; numbers refer to the new metabolite peaks.

mainly saturated and unsaturated fatty acids ( $>96 \%)$, and only small amounts of hydroxy fatty acid were present $(<4 \%)$. These data show that compound IV inhibits LPS synthesis in $A$. tumefaciens, resulting in the appearance of two new metabolites which are radiolabelled with glucosamine, and contain hydroxy fatty acids.

Similar results were obtained with $A$. salmonicida. Growth gradually ceased following addition of greater than $50 \mu \mathrm{g}$ compound IV $\mathrm{ml}^{-1}$, LPS synthesis was inhibited, and two new metabolites appeared (Fig. $2 b$ ). These new metabolites were also radiolabelled with acetate and recovered from the TLC. More than $94 \%$ of the fatty acids released from the two new metabolites were hydroxy fatty acids, while fatty acid released from

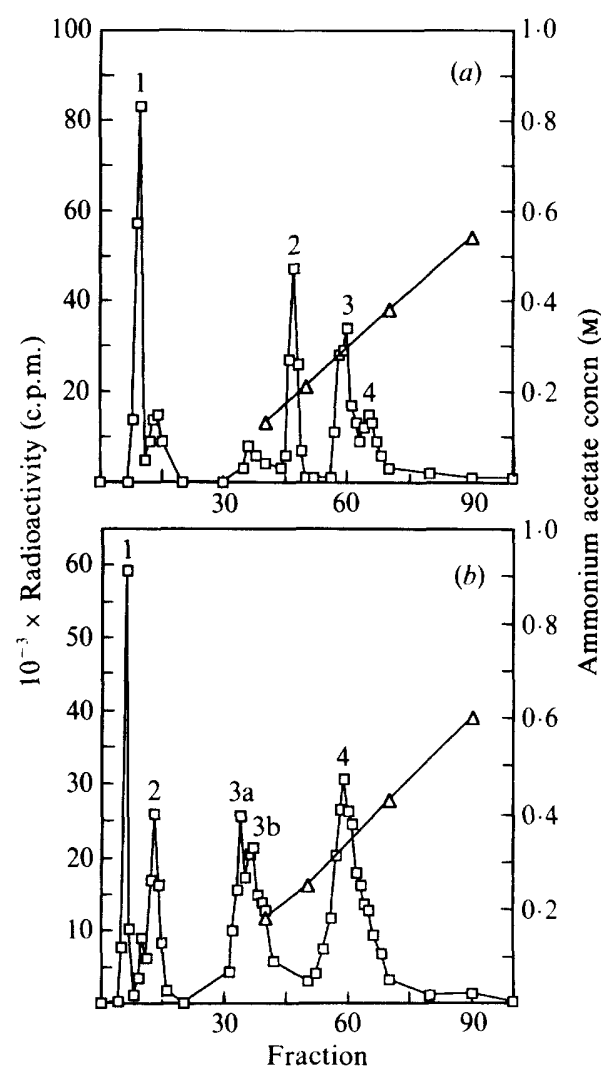

Fig. 3. Purification of lipid A metabolites by DEAE-cellulose chromatography. Drug-treated bacteria were radiolabelled with $\mathrm{N}$-acetylD- $\left[1-{ }^{3} \mathrm{H}\right]$ glucosamine, delipidated, and their glycolipids extracted with phenol/chloroform/petroleum ether $(2: 5: 8)$. The phenol phase was loaded onto a DEAE-cellulose column equilibrated with methanol containing $1 \%(\mathrm{v} / \mathrm{v})$ acetic acid. The column was washed with equilibration buffer, and eluted with a linear gradient of 0 to $1 \mathrm{M}$ ammonium acetate. Fractions were monitored for radioactivity. (a) Material extracted from $A$. tumefaciens strain 136 treated with $20 \mu \mathrm{g}$ compound IV ml $\mathrm{m}^{-1}$ for $3 \mathrm{~h}$. (b) Material extracted from $A$. salmonicida treated with $50 \mu \mathrm{g} \mathrm{ml}^{-1}$ for $6 \mathrm{~h}$. Symbols: $\square$, radioactivity; $\triangle$, ammonium acetate.

phospholipid contained mainly saturated and unsaturated fatty acid $(>93 \%)$.

\section{Purification and chemical analysis of accumulated lipid $A$ metabolites}

Radiolabelled lipid A metabolites, accumulated following addition of compound IV to $A$. tumefaciens strain A136 and $A$. salmonicida, were extracted from 11 delipidated cells, and fractionated on DEAE-cellulose (Fig. 3a). Two peaks eluted from the column during the wash with equilibration buffer and four peaks were bound and eluted with a subsequent ammonium acetate gradient during analysis of material extracted from $A$. tumefaciens. Peaks 1-4 were collected for further analysis by TLC. These fractions contained the following 
components by TLC analysis: (peak 1), material comigrating with LPS and phospholipid ; (peak 2), phospholipid; (peak 3), the faster-migrating metabolite, designated 2 in Fig. $2(a)$; and (peak 4), the slower-migrating metabolite, designated peak 1 in Fig. 2(a). Peak 1 contained $13.9 \mathrm{nmol}$ phosphate and less than $6 \mathrm{nmol}$ glucosamine, while peak 2 contained $490 \mathrm{nmol}$ phosphate and less than $5 \mathrm{nmol}$ glucosamine. The yield of phosphate, glucosamine, and 3-OH-C14:0 from peak 3 was $74 \cdot 0( \pm 0 \cdot 6), 85 \cdot 0$ $( \pm 16 \cdot 2)$ and $106 \cdot 3( \pm 3 \cdot 5) \mathrm{nmol}$, respectively $(n=3)$. Given the range in the glucosamine data, it appears that these components were present in approximately equal molar ratios. The low amounts of peak 4 precluded complete analysis; however $27.9( \pm 5.9)$ and 16.2 $( \pm 1 \cdot 7)$

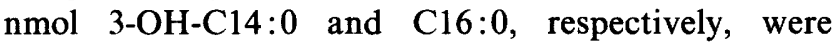
recovered. LPS from $A$. tumefaciens is not well characterized, but 3-OH-C14:0 and 3-OH-C16:0 were reported as the major fatty acid constituents from strains 0362 and TT111 (Salkinoja-Salonen \& Boeck, 1978). Our analysis of LPS (Fig. 4) and LPS precursor prepared from strain A136 yielded $3 \mathrm{OH}-\mathrm{C} 14: 0$ as the major fatty acid component. The fatty acid composition we determined for LPS was $11( \pm 0 \cdot 1) \mu \mathrm{mol} 3-\mathrm{OH}-\mathrm{C} 14: 0,1 \cdot 7( \pm 0 \cdot 3)$ $\mu \mathrm{mol} \mathrm{C18:1}$ and $1 \cdot 2( \pm 0 \cdot 1) \mu \mathrm{mol} \mathrm{C16:0}$ per g. Since $3 \mathrm{OH}-\mathrm{C} 16: 0$ is not available as a standard to use for determining retention time and response factor, we cannot be certain as to its presence or absence in LPS and LPS precursor from A. tumefaciens. It is possible that the minor peak preceding the internal standard $(\mathrm{C17:0)}$ is $3 \mathrm{OH}-\mathrm{C} 16: 0$, or that $3 \mathrm{OH}-\mathrm{C} 16: 0$ is not separating from $\mathrm{C17:0}$ in our gas chromatographic system (Fig. 4). Additional studies would be required to answer this question.

Similarly, multiple peaks were recovered by chromatography of the extract prepared from $A$. salmonicida on DEAE-cellulose (Fig. $3 b$ ). Peak 4 contained both of the metabolites detected by TLC (Fig. 2b) free from phospholipid and other metabolites, while phospholipid was the major component of peaks $3 \mathrm{a}$ and $3 \mathrm{~b}$. Peaks 1 and 2 were not examined further. Material recovered from peak 4 yielded $(n=3)$ phosphate $(116.8 \pm 0.3 \mathrm{nmol})$, glucosamine $(118.7 \pm 8.7 \mathrm{nmol})$ and $3-\mathrm{OH}-\mathrm{C} 14: 0(162.6 \pm 8.3 \mathrm{nmol})$, demonstrating the presence of one phosphate per glucosamine. The relatively higher molar ratio for $3-\mathrm{OH}-\mathrm{C} 14: 0(1.37$ per mol glucosamine) coupled with data accuracy, may reflect the partial loss of ester-linked 3-OH-C14:0 during extraction (i.e. the ratio may be 2 per mol glucosamine). Our fatty acid analysis of LPS gave $61( \pm 3.5) \mu \mathrm{mol} \mathrm{3-}$ OH-C14:0, 5.1 ( $\pm 0 \cdot 2) \mu \mathrm{mol} \mathrm{C16:1,} 15 \cdot 3( \pm 1 \cdot 2) \mu \mathrm{mol}$ $\mathrm{C} 12: 0$ and $2 \cdot 8( \pm 0 \cdot 2) \mu \mathrm{mol} \mathrm{C14:0}$ per $\mathrm{g}$. Glucosamine content was not determined.

Although more than one lipid A metabolite accumulates when the KDO pathway is inhibited in various

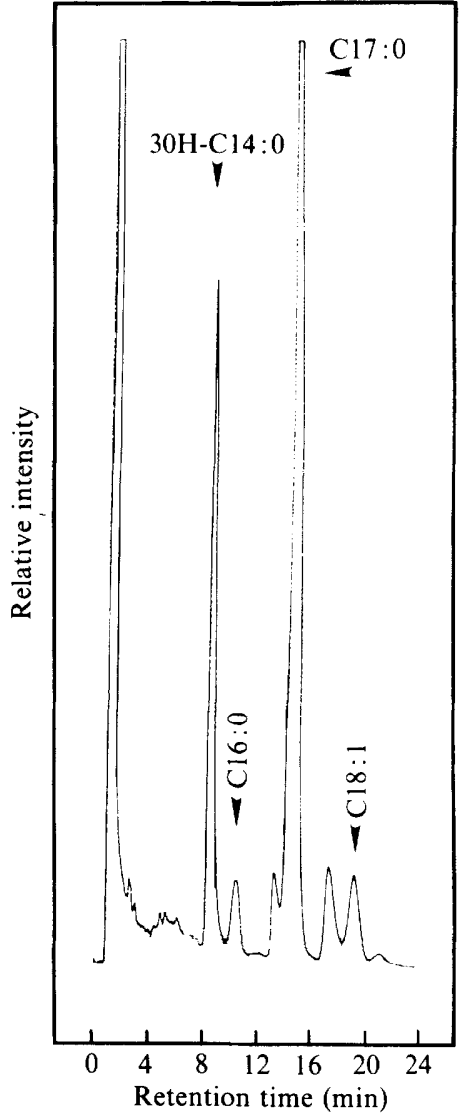

Fig. 4. Fatty acid analysis of LPS prepared from A. tumefaciens strain 136. LPS was purified, and samples containing the internal standard heptadecanoic acid were converted to methyl esters with methanolic $\mathrm{HCl}$. Methyl esters were extracted into chloroform prior to injection into the gas chromatograph.

Gram-negative bacteria (Goldman et al., 1987, 1988a, $b$; Kadam et al., 1989; Raetz et al., 1985), a single lipid A metabolite, designated $\mathrm{IV}_{\mathrm{A}}$, was identified as the direct precursor to mature LPS (Goldman et al., 1988a; Kadam et al., 1989). This same metabolite is also the preferred substrate to which KDO is added in an in vitro system (Brozek et al., 1989). Metabolite $\mathrm{IV}_{\mathrm{A}}$ was the major component accumulated, and was the first to appear following inhibition of LPS synthesis. Minor components which were not direct precursors to LPS accumulated gradually with time, and only after the major component had reached near-maximum values (Goldman et al., 1988a). Similarly in $A$. tumefaciens the major metabolite (TLC peak 2, Fig. $2 a$ ) appeared earlier than the minor component (peak 1) and chased more efficiently to LPS (data not shown). The slower migrating species (peak 2, Fig. $2 a$ ) in $A$. tumefaciens also contained $\mathrm{C} 16: 0$, which is not a normal component of $A$. tumefaciens LPS (Salkinoja-Salonen \& Boeck, 1978). We found less than one C16:0 for each 


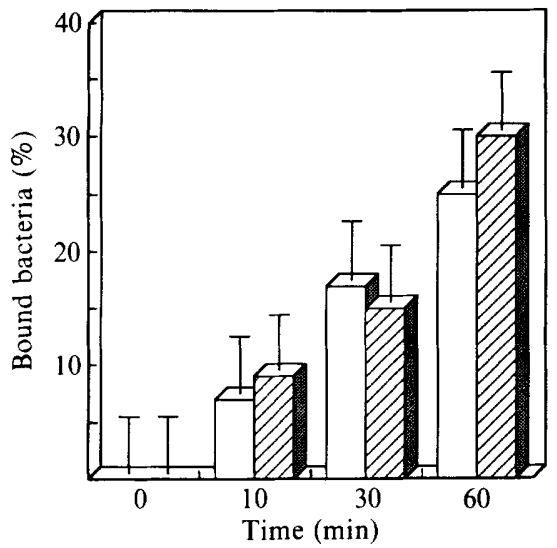

Fig. 5. Effect of inhibition of LPS synthesis on the attachment of $A$. tumefaciens strain 136 to carrot cells. Bacteria were treated with drug $\left(20 \mu \mathrm{g} \mathrm{ml}^{-1}\right)$ for $4 \mathrm{~h}$ and the initial kinetics of attachment to carrot cells were monitored relative to control bacteria. The fraction of bacteria attached was determined by viable count of free and bound bacteria $(n=3) \pm$ standard deviation. $\square$, control; $\square$, drug-treated bacteria.

3-OH-C14:0 present in LPS from strain A136. These data indicate that aberrant addition of $\mathrm{C} 16: 0$ may occur in $A$. tumefaciens during inhibition of the KDO pathway, as occurs in $S$. typhimurium (Raetz et al., 1985). These data, along with our previous studies of other Gramnegative bacteria, indicate that the major metabolite which accumulates and migrates fastest on Silica Gel $\mathbf{H}$ chromatography is the direct precursor to LPS in $A$. tumefaciens and $A$. salmonicida. Although not rigorously examined in the present study, the slower-migrating metabolites are likely aberrant side-products.

\section{Effect of LPS inhibition on the interaction with carrot cells}

Attachment of $A$. tumefaciens to wound sites on plants involves a specific, but incompletely defined interaction between the bacterium and plant cell surfaces (see Matthysse, 1986 for review). This interaction is required for the disease process to continue, and avirulent mutants which are defective in this step have been isolated (Matthysse, 1986). There is evidence implicating the involvement of LPS, protein, and LPS-protein complexes as the bacterial components involved in initial attachment. The data for LPS involvement is based on the ability of isolated LPS to block tumour formation if applied to wound sites prior to infection with $A$. tumefaciens, and the fact that transfer of $\mathrm{pTi}$ (the virulence plasmid) to non-attaching, avirulent $A$. radiobacter results in a strain which attaches, is virulent, and contains LPS capable of blocking tumour formation (Whatley et al., 1976). In addition, LPS can inhibit attachment of $A$. tumefaciens to cultured plant cells with $\mathrm{IC}_{50}$ values of $0 \cdot 2-1 \mu \mathrm{g} \mathrm{ml}^{-1}$ (based on $\mathrm{KDO}$ equivalents). In contrast, LPS from five of six A. tumefaciens strains did not inhibit bacterial attachment to potato tuber slices (Pueppke \& Benny, 1984), and avirulent mutants with altered LPS were recently shown to attach normally to plant cells (Metts et al., 1991). Other studies have implicated bacterial surface proteins as components of the initial bacterial-plant cell interaction (Matthysse, 1987). Analysis of bacterial attachment is further complicated by the facts that (i) not all bacteria in a population of a given strain are able to bind (Matthysse, 1986), indicating that the attachment phenotype is not fully expressed in all bacteria under the incubation conditions used, and (ii) non-specific effects of LPS on bacterial attachment and subsequent events in tumour formation have not been ruled out.

Inasmuch as compound IV inhibits LPS synthesis in $A$. tumefaciens, we investigated the effects of such inhibition on the ability of $A$. tumefaciens to attach to plant suspension culture cells. Bacteria growing in MOPS medium were treated with $20 \mu \mathrm{g}$ compound IV $\mathrm{ml}^{-1}$ for 3-4 h and then tested for their ability to bind to plant suspension culture cells. Attachment of treated cells was identical to that of control cells during the initial 60 min (Fig. 5) demonstrating that inhibition of LPS synthesis had no effect on the initial kinetics of the attachment process. Binding at later time periods was not studied in detail, owing to complexities in the analysis of control samples (trapping and binding of bacteria to cellulose fibrils, and growth of bacteria upon recovery from the shift down into plant tissue culture media). Binding of drug-treated bacteria, which do not replicate, did plateau at a value of $30 \%$ bacteria bound at 60 and $120 \mathrm{~min}$. Aggregation of plant cells by bacterial cellulose occurred as expected in control experiments (Matthyse et al., 1981), but bacterial aggregation induced by cellulose was inhibited upon incubation with $20 \mu \mathrm{g}$ compound IV $\mathrm{ml}^{-1}$ (data not shown). Similar results were observed for strain A6. Bacteria treated with drug for $24 \mathrm{~h}$ were still as able to attach to plant cells as control cells incubated for $24 \mathrm{~h}$ in MOPS alone (data not shown). Microscopic observation showed no differences between attachment of control or drug-treated cells to plant cells, and normal cytoplasmic streaming was maintained in plant cells.

Since compound IV was included at $20 \mu \mathrm{g} \mathrm{ml}^{-1}$ during the incubation of bacteria with carrot cells, we examined the effect of prolonged exposure. Compound IV had no effect on viability of $A$. tumefaciens strain A136 even after $24 \mathrm{~h}$ incubation at $30^{\circ} \mathrm{C}$ (data not shown) even though growth ceased after 4-5 h. Radioactive phenylalanine was incorporated into growing bacteria at a rate of $1.7 \times 10^{4}$ d.p.m. min $^{-1}$ (mg cell protein) ${ }^{-1}$, and incorpor- 
ation continued at the rate of $2.14 \times 10^{3}$ and $2.51 \times 10^{3}$ d.p.m. $\min ^{-1}$ (mg cell protein $)^{-1}$ in cells treated with compound IV $\left(20 \mu \mathrm{g} \mathrm{ml}^{-1}\right)$ for 5 and $24 \mathrm{~h}$, respectively. Incorporation of radiolabel was inhibited by more than $95 \%$ when cells were pretreated for $10 \mathrm{~min}$ with $25 \mu \mathrm{g}$ tetracycline $\mathrm{ml}^{-1}$. Pulse rates of incorporation were determined in duplicate, linear $\left(r^{2}>0.96\right)$, and accurate to better than $5 \%$ error. Furthermore, when the drug was removed from cells exposed to drug for $24 \mathrm{~h}$, bacterial growth resumed within $5 \mathrm{~h}$ of incubation in fresh medium. These data show that bacteria were still viable and capable of protein synthesis (most likely via protein turnover) at a rate $15 \%$ that of growing cells, during the course of the experiments. In addition, A. tumefaciens binds to carrot cells in the presence of inhibitors of bacterial protein synthesis (Matthysse, 1986). We conclude that continued synthesis of LPS is not required for bacterial attachment to carrot cells, although preexisting LPS may be involved. In addition, the lack of cellulose-induced aggregation was not due to the inability of bacteria to synthesize protein, but more likely their inability to (i) make sufficient protein, (ii) specific proteins, (iii) respond normally to the bacterial-plant cell interaction or (iv) a combination of these possibilities.

\section{References}

Ames, B. N. (1966). Assay of inorganic phosphate, total phosphate and phosphatases. Methods in Enzymology 8, 115-118.

BARK. Z. \& GILVARG, C. (1974). Triornithine-resistant strains of Escherichia coli. Journal of Biological Chemistry 249, 143-148.

Brozex, K., Hosaka, K., Robertson, D. \& Raetz, C. (1989). Biosynthesis of lipopolysaccharide in Escherichia coli. Cytoplasmic enzymes that attach 3-deoxy-D-manno-octulosonic acid to lipid A. Journal of Biological Chemistry 264, 6956-6966.

Capobianco, J. O., Darveau, R. P., Goldman, R. C., Lartey, P. A. \& Pernet, A. G. (1987). Inhibition of exogenous 3-deoxy-D-mannooctulosonate incorporation into lipid A precursor of toluene-treated Salmonella typhimurium cells. Journal of Bacteriology 169, 4030-4035.

Goldman, R. C. \& Miller, M. F. (1989). Complement attack of altered outer membrane areas synthesized after inhibition of the 3deoxy-D-manno-octulosonate pathway leads to cell death. Journal of Immunology 142, 185-194.

Goldman, R. C., Kohlbrenner, W. E., Lartey, P. A. \& Pernet, A. G. (1987). Antibacterial agents specifically inhibiting lipopolysaccharide synthesis. Nature, London 329, 162-164.

Goldman, R. C., Doran, C. C. \& CaPobianco, J. O. (1988a). Analysis of lipopolysaccharide synthesis in Salmonella typhimurium and Escherichia coli by using agents which specifically block incorporation of 3-deoxy-D-manno-octulosonate. Journal of Bacteriology 170, 2185-2191.

Goldman, R. C., Doran, C. C., Kadam, S. K. \& Capobianco, J. O. $(1988 b)$. Lipid A precursor from Pseudomonas aeruginosa is completely acylated prior to addition of 3-deoxy-D-manno-octulosonate. Journal of Biological Chemistry 263, 5217-5223.

Goldman, R. C., Doran, C. C. \& Capobianco, J. O. (1990). Antibacterial agents which specifically inhibit lipopolysaccharide synthesis. In Cellular and Molecular Aspects of Endotoxin Reactions.
Excerpta Medica International Congress Series 923, pp. 1576-1586. Edited by A. Nowotny, J. J. Spitzer \& E. J. Ziegler. Amsterdam: Elsevier Science Publishers.

Hiles, I. D., Powell, L. M. \& Higgins, C. F. (1987). Peptide transport in Salmonella typhimurium: molecular cloning and characterization of the oligopeptide permease genes. Molecular and General Genetics 206, 101-109.

Kadam, S. K., Doran, C. C. \& Goldman, R. C. (1989). Accumulation of incomplete metabolic side products of lipid A in Salmonella typhimurium during inhibition of 3-deoxy-D-manno-octulosonate incorporation by a new class of antibacterial agents. Canadian Journal of Microbiology 35, 646-650.

KlontZ, G. W., Yasutake, W. T. \& Ross, A. J. (1966). Bacterial disease of the Salmonidae in the Western United States. Pathogenesis of furunculosis in rainbow trout. American Journal of Veterinary Research 27, 1455-1460.

Levvy, G. A. \& McAllen, A. (1959). The $N$-acetylation and estimation of hexosamines. Biochemistry 73, 127-132.

LIPPINCOTT, J. A. \& LIPPINCOTT, B. B. (1975). The genus Agrobacterium and plant tumorigenesis. Annual Review of Microbiology 29, 377-405.

MATTHYSSE, A. G. (1986) Initial interactions of Agrobacterium tumefaciens with plant host cells. CRC Critical Reviews in Microbiology 13, 281-307.

MATTHYSSE, A. G. (1987). Characterization of nonattaching mutants of Agrobacterium tumefaciens. Journal of Bacteriology 169, 313-323.

Matthysse, A. G., Wyman, P. M. \& Holmes, K. V. (1978). Plasmid dependent attachment of Agrobacterium tumefaciens to plant tissue culture cells. Infection and Immunity 22, 516-522.

Matthysse, A. G., Holmes, K. V. \& Gurlitz, R. H. G. (1981). Elaboration of cellulose fibrils by Agrobacterium tumefaciens during attachment to carrot cells. Journal of Bacteriology 145, 583-595.

MetTS, J., West, J., Doares, S. H. \& Matthysse, A. J. (1991). Characterization of three Agrobacterium tumefaciens avirulent mutants with chromosomal mutations that affect induction of vir genes. Journal of Bacteriology 173, 1080-1087.

Neidhardt, F. C., Bloch, P. L. \& Smith, D. F. (1974). Culture medium for enterobacteria. Journal of Bacteriology 119, 736-747.

OSBORN, M. J., RICK, P. D. \& RASMUSSEN, N. S. (1980). Mechanism of assembly of the outer membrane of Salmonella typhimurium. Translocation and integration of an incomplete lipid A precursor into the outer membrane. Journal of Biological Chemistry 255, 4246 4251.

Pueppke, S. G. \& BenNy, U. K. (1984). Adsorption of tumorigenic Agrobacterium tumefaciens cells to susceptible potato tuber tissues. Canadian Journal of Microbiology 30, 1030-1037.

Pugh, E. L., Sauer, F., Waite, M., Toomey, R. E. \& Wakil, S. J. (1966). Studies on the mechanism of fatty acid synthesis. XIII. The role of $\beta$-hydroxy acids in the synthesis of palmitate and cisvaccenate by the Escherichia coli enzyme system. Journal of Biological Chemistry 241, 2635-2643.

Raetz, C. R. H., Purcell, S., Meyer, M. V., Qureshi, N. \& TAKAYAMA, K. (1985). Isolation of eight lipid A precursors from a 3deoxy-D-manno-octulosonic acid-deficient mutant of Salmonella typhimurium. Journal of Biological Chemistry 260, 16080-16088.

Ray, P. H., Kelsey, J. E., Bigham, E. C., Benedict, C. \& Miller, T. (1982). Synthesis and utilization of KDO (3-deoxy-D-manno-octulosonate) in Escherichia coli: potential sites of inhibition. In Bacterial Lipopolysaccharides, pp. 141-169. Edited by L. Anderson \& F. Unger. Washington, DC: American Chemical Society.

Reissig, J. L., Strominger, J. L. \& Leloir, L. F. (1955). A modified colorimetric method for the estimation of $N$-acetylamino sugars. Journal of Biochemistry 217, 958-966.

Salkinoja-Salonen, M. \& Boeck, B. (1978). Characterization of the lipopolysaccharides isolated from Agrobacterium tumefaciens. Journal of General Microbiology 105, 119-125.

WhATLEY, M. H., BodWIN, J. S., LipPINCOTT, B. B. \& LiPPINCOTT, J. A. (1976). Role of Agrobacterium cell envelope lipopolysaccharide in infection site attachment. Infection and Immunity 13, 1080-1083. 